\title{
'Floral' scent production by Puccinia rust fungi that mimic flowers
}

\author{
ROBERT A. RAGUSO* $\neq$ and BARBARA A. ROY + \\ *Department of Biology, University of Michigan, Ann Arbor, MI 48109-1048, USA, +Geobotanisches Institut, Swiss Federal \\ Institute of Technology (ETH), Zürichbergstrasse 38, CH-8044 Zürich, Switzerland
}

\begin{abstract}
Crucifers (Brassicaceae) in $\mathbf{1 1}$ genera are often infected by rust fungi in the Puccinia monoica complex. Infection causes a 'pseudoflower' to form that is important for attracting insect visitors that sexually outcross the fungus. 'Pollinator' attraction is accomplished through visual floral mimicry, the presence of a nectar reward and floral fragrances. Here we used gas chromatography and mass spectrometry to identify and quantify fragrance production by these rust fungi on several Arabis hosts, and by co-occurring true flowers that share insect visitors. Fungal pseudoflowers produced distinctive floral fragrances composed primarily of aromatic alcohols, aldehydes and esters. Pseudoflower fragrances were chemically similar to noctuid-moth-pollinated flowers, such as Cestrum nocturnum and Abelia grandiflora, but were very different from host flowers, host vegetation and the flowers of coblooming, nonhost angiosperms. There was variation in the quantity and composition of fragrance profiles from different fungal species as well as within and among hosts. The evolution of scent chemistry is relatively conservative in these fungi and can be most parsimoniously explained in three steps by combining chemical data with a previously determined rDNA ITS sequence-based phylogeny. Pseudoflower scent does not appear to represent a simple modification of host floral or vegetative emissions, nor does it mimic the scent of coblooming flowers. Instead, we suspect that the unique fragrances, beyond their function as pollinator attractants, may be important in reducing gamete loss by reinforcing constancy among foraging insects.
\end{abstract}

Keywords: gas chromatography, headspace volatiles, ITS region, mass spectrometry, phylogenetic reconstruction, pollination

Received 2 September 1997; revision received 13 February 1998; accepted 23 February 1998

\section{Introduction}

Rust fungi in the Puccinia monoica complex (Pucciniaceae, Uredinales, Basidiomycetes) infect 11 species of Brassicaceae throughout the northern hemisphere, modifying host leaf morphology to produce fungal 'pseudoflowers' that aid in the sexual reproduction of the fungus through the movements of foraging insects (Roy 1993a; 1994a, b). Rosettes of infected leaves are encrusted by bright yellow spermagonia (the outcrossing fungal structures that bear spermatia and receptive hyphae) and visually resemble yellow coblooming true flowers. Not only

Correspondence: R. A. Raguso. $¥$ Present address for correspondence: Center for Insect Science and ARL Div. of Neurobiology, 611 Gould-Simpson Building, University of Arizona, Tucson AZ 85721, USA. Fax: +1-520-621-8385; E-mail: rar@neurobio. arizona.edu do Puccinia pseudoflowers look like flowers, they also produce a sweet, pungent fragrance and exude a fructoserich solution that is consumed by numerous insects, including andrenid and halictid bees, ants, nymphalid butterflies, anthomyiid, muscid and sarcophagid flies (Roy 1993a; 1996; Roy \& Raguso 1997). Thus, pseudoflowers produce 'floral' advertisements and rewards and may be considered generalized floral mimics (Roy 1993a, 1994a, 1996).

We previously demonstrated that both visual and olfactory cues attract bees and flies to fungal pseudoflowers in field settings (Roy \& Raguso 1997). Halictid bees (Dialictus spp.) were attracted to yellow paper artificial flowers and to lures charged with complete and fractionated pseudoflower fragrance, but the combination of yellow colour and Puccinia scent was required to elicit normal levels of bee approaches and landings. In contrast, 
anthomyiid flies were not attracted to yellow colour alone, nor to individual scent compounds, but only to the complete blend of pseudoflower volatiles (Roy \& Raguso 1997). Thus, fragrance production appears to be an important component of insect attraction and sexual reproduction in Puccinia monoica and related rust fungi.

Here we identify the fragrance compounds produced by fungal pseudoflowers on Arabis and compare them with: (i) the vegetative and floral volatiles of their uninfected host Arabis plants; and (ii) the floral volatiles of coblooming plants in Colorado, USA, with which Puccinia pseudoflowers share insect visitors. In addition, we analysed variation in scent production by pseudoflowers in a phylogenetic context, searching for intra- and interspecific differences in fragrance chemistry that are correlated with host species. Specifically, we asked: do flower-mimicking crucifer rust fungi emit amplified levels of volatiles already produced by host vegetation and flowers, or are their fragrance compounds unique to infected tissues? Are pseudoflower fragrances similar to those of some coblooming flowers, or are they chemically distinct? How has fragrance production evolved in this floral mimicry system?

\section{Materials and methods}

Plant and fungal materials were collected at numerous localities, including Almont, Cement Creek and Taylor River (2500-2700 m; see Roy 1996) near the Rocky Mt. Biological Laboratory in Gunnison County, Colorado, USA. We enclosed cut Arabis leaves, flowers, and tissues infected with Puccinia rust fungus within $0.5 \mathrm{~L}$ polyacetate bags (Reynolds, Inc.). Due to the small masses and relative weakness of fragrance in these samples, tissues from many individuals were combined so that each trial had a minimum of $\approx 0.5 \mathrm{~g}$ of plant/ fungal tissue. In addition, we collected and identified floral scent compounds from Anemone (Pulsatilla) patens and Ranunculus inamoenus (Ranunculaceae), Phlox bryoides (Polemoniaceae), Pseudocymopterus montanus (Apiaceae) and Thlaspi montanus (Brassicaceae) plants that share flowering phenology, habitat and insect visitors with Puccinia pseudoflowers. Headspace volatiles accumulated in the bags and were swept over cylindrical glass cartridges packed with $100 \mathrm{mg}$ of Porapak Q sorbent (80-100 mesh) by a Manostat, Inc. peristaltic vacuum pump at a flow rate of $250 \mathrm{~mL} / \mathrm{min}$ for $8 \mathrm{~h}$. Trapped volatiles were eluted from cartridges with $3 \mathrm{~mL}$ of HPLC-grade hexane, concentrated to a $50 \mu \mathrm{L}$ volume with gaseous $\mathrm{N}_{2}$, and supplemented with toluene (5 $\mu \mathrm{L}$ of a $0.3 \% \mathrm{v} / \mathrm{v}$ solution in hexane) as an internal standard.

Fragrance compounds were analysed by injecting $1 \mu \mathrm{L}$ aliquots of processed samples into a Shimadzu GC17A gas chromatograph, using a Shimadzu QP5000 mass spectrometer as a detector. Constituent peaks were separated on a nonpolar SE-54 glass capillary column (30 m long, $0.32 \mathrm{~mm}$ internal diameter (ID), $1 \mu \mathrm{m}$ film thickness) using the following temperature program: inject at $50{ }^{\circ} \mathrm{C}$ and hold for $2 \mathrm{~min}$, then increase at $10^{\circ} \mathrm{C} / \mathrm{min}$ to $275^{\circ} \mathrm{C}$, hold for $3.5 \mathrm{~min}$ ). Tentative identifications of scent compounds were provided by on-line mass spectral libraries (Wiley and NIST, > 125000 spectra) and confirmed, when possible, through comparison with retention times and mass spectra of synthetic standards (Sigma Inc. and Aldrich Inc.). Integrated peak areas were quantified by comparison with the internal standard (toluene) and with calibration curves based on serial dilutions of other standards.

\section{Results}

\section{Volatiles from uninfected Arabis vegetative tissues}

We identified numerous fatty-acid-derived volatiles, a few aromatics and one sesquiterpene from the vegetation of six Arabis species (Table 1). The vegetative headspace of these plants was dominated by the 'green-leaf volatiles' (GLVs), a class of $\mathrm{C}_{6}-\mathrm{C}_{8}$ aliphatic compounds that are ubiquitous in vegetative tissues, especially when cut or wounded, and are derived from linolenic acid through the catabolic lipoxygenase pathway (Visser \& Avé 1978, Tollsten \& Bergström 1988; Mookherjee et al. 1989; Buttery \& Ling 1993; Dickens et al. 1993). In addition, we identified isopropyl isothiocyanate, a glucosinolate derivative that is characteristic of crucifer foliage (Fenwick et al. 1983; Tollsten \& Bergström 1988; Evans \& Allen-Williams 1992), from the vegetative headspace of $A$. crandallii and A. holboellii. Within A. holboellii, rosette leaves differed from bolting leaves in overall volatile emissions per fresh mass and in the presence of the aromatic compounds benzaldehyde and benzyl alcohol (Table 1). Bolting leaves were used for all other Arabis samples.

\section{Volatiles from uninfected Arabis flowers}

Volatile emissions from floral tissues of A. demissa, A. drummondii and $A$. holboellii were barely detectable, and included the sesquiterpene caryophyllene, aliphatic GLVs (probably from vegetative tissues) and trace amounts of the aromatic 2-phenyl ethanol and the nitrogen-bearing indole (Table 1). Most of these compounds have been previously identified from the vegetative and floral headspace of other crucifers, including Brassica napus, B. campestris, B. juncea, B. nigra (Tollsten \& Bergström 1988; Evans \& Allen-Williams 1992, Jakobsen et al. 1994), Hesperis matronalis (Nielsen et al. 1995) and Sinapis alba (Tollsten \& Bergström 1988).

\section{Volatiles from Puccinia fungal pseudoflowers}

Arabis vegetative tissues infected with Puccinia rust fungus produced numerous structurally related aromatic or 
Table 1 Volatile production from uninfected Arabis plants

\begin{tabular}{|c|c|c|c|c|c|c|c|c|c|c|}
\hline \multirow{2}{*}{$\begin{array}{l}\text { Chemical class } \\
\text { compound }\end{array}$} & \multicolumn{3}{|c|}{ A. holboellii } & \multicolumn{2}{|c|}{ A. demissa } & \multirow{2}{*}{$\frac{\text { A. crandallii }}{\text { veg }}$} & \multirow{2}{*}{$\frac{\text { A. lignifera }}{\text { veg }}$} & \multicolumn{2}{|c|}{ A. drummondii } & \multirow{2}{*}{$\frac{\text { A. gunnisoniana }}{\text { veg }}$} \\
\hline & veg* & vegt & floral & veg & floral & & & veg & floral & \\
\hline \multicolumn{11}{|l|}{ Aromatics } \\
\hline Benzaldehyde & $19.28 \% \ddagger$ & & & & & & & & ND & \\
\hline Benzyl alcohol & 24.19 & & & & & & & & & \\
\hline Indole & & $<1.0$ & & & 26.51 & $<1.0$ & $<1.0$ & & & \\
\hline 2-phenylethanol & & & & & $<1.0$ & & & & & \\
\hline \multicolumn{11}{|l|}{ Terpenoids } \\
\hline Caryophyllene & & & 50.00 & & & & & & & \\
\hline \multicolumn{11}{|l|}{ Fatty acid derivatives } \\
\hline 1-hexanol & & 11.07 & & & & 13.60 & & & & \\
\hline$n$-hexanal & & 13.47 & & 20.00 & & 29.30 & & & & \\
\hline 2-ethyl hexanol§ & & 1.63 & & & & & & & & \\
\hline Hexyl acetate & & 2.20 & & & & & & & & \\
\hline (Z)-3-hexen-1-ol & & & & & & & & & & 20.6 \\
\hline (Z)-3-hexenal & 9.24 & 59.00 & & 80.00 & & 43.80 & 29.33 & 34.55 & & \\
\hline (Z)-3-hexenyl acetate & 29.65 & 8.79 & & & 57.14 & 8.30 & 36.48 & 33.20 & & 79.4 \\
\hline (Z)-3-hexenyl butyrate & & & & & & & & 6.09 & & \\
\hline (Z)-3-hexenyl & 4.16 & 3.83 & 50.00 & & 16.65 & 2.36 & 34.19 & 12.61 & & \\
\hline \multicolumn{11}{|l|}{ 3-methyl butyrate } \\
\hline 2-methyl butyrate & & & & & & & & 12.52 & & \\
\hline Diethyl ethanone§ & & & & & & & & 1.00 & & \\
\hline Isopropyl iso- & 8.49 & & & & & 2.65 & & & & \\
\hline thiocyanate octadecanal§ & & & & & $<1.0$ & & & & & \\
\hline Total fresh mass $(\mathrm{g})$ & 4.23 & 1.21 & 0.50 & 0.59 & 1.13 & 1.94 & 3.56 & 4.06 & 0.70 & 7.24 \\
\hline $\begin{array}{l}\text { Emissions } \\
\mathrm{ng} / \mathrm{g} \text { fresh mass } / 8 \mathrm{~h}\end{array}$ & 0.27 & 8.36 & 1.55 & 6.45 & 6.65 & 2.88 & 0.05 & 0.22 & ND & 0.30 \\
\hline
\end{tabular}

*Leaves taken from bolting tissues.

tLeaves taken from basal rosette.

$\ddagger$ Per cent of total volatile emissions.

§Indicates tentative identification due to mass spectrum library search. All other identifications verified by mass spectrum and retention time through coinjection of standards.

benzenoid compounds, such as benzaldehyde, phenylacetaldehyde and various phenylethyl esters (Tables 2 and 3), in addition to aliphatic GLVs that are emitted by uninfected Arabis foliage (Table 1, Fig. 1). Phenylacetaldehyde and 2-phenyl ethanol were present in all Puccinia samples and, to our human noses, were the dominant 'characterbearing notes' of the distinctive pseudoflower fragrance. One aromatic ester, benzyl acetate, was only detected in the headspace of some (but not all) A. crandallii plants infected with $P$. consimilis (Table 2, 3). Interestingly, benzyl acetate was not detected when $P$. consimilis used $A$. lignifera as a host. In addition, we identified what appears to be an $\alpha$-oxidation series of phenylethyl esters (Fig. 1; see Croteau \& Karp 1991), ranging in size from phenylethyl senecioate and phenylethyl isovalerate $\left(C_{13}\right)$ to phenylethyl acetate $\left(\mathrm{C}_{10}\right)$. Scent profiles did not vary greatly between fungal species or between host races within fungal species (Tables 2 and 3), except in cases where poor scent production was probably an artefact of small, senescent tissue samples (P. monoica on A. drummondii and P. thlaspeos on A. demissa). Two additional aromatic esters, methyl benzoate and amyl salicylate, were detected in most samples in 1994 and were absent in 1996, but were not present as contaminants in ambient controls. Phenylacetaldehyde, 2-phenylethanol, and benzaldehyde (along with indole) were previously identified from the headspace of another rust fungus, $P$. punctiformis, which uses Cirsium arvense thistles as a sexual stage host but does not modify host vegetation to produce pseudoflowers (Connick \& French 1991).

\section{Volatiles from coblooming alpine flowers}

The floral fragrances of Anemone patens, Phlox bryoides, Pseudocymopterus montanus and Thlaspi montanus were dominated by monoterpenoid compounds, especially 
Table 2 Volatiles emitted by Puccinia rust fungi associated with Arabis host plants: 1994

\begin{tabular}{|c|c|c|c|c|c|}
\hline $\begin{array}{l}\text { Chemical class } \\
\text { compounds }\end{array}$ & $\begin{array}{l}\text { P. monoica on } \\
\text { A. holboellii }\end{array}$ & $\begin{array}{l}\text { P. consimilus on } \\
\text { A. crandallii }\end{array}$ & $\begin{array}{l}\text { P. consimilus on } \\
\text { A. demissa }\end{array}$ & $\begin{array}{l}\text { P. thlaspeos on } \\
\text { A. gunnisoniana }\end{array}$ & $\begin{array}{l}\text { P. thlaspeos on } \\
\text { A. holboellii }\end{array}$ \\
\hline \multicolumn{6}{|l|}{ Aromatics } \\
\hline Benzaldehyde & $3.4 \% *$ & 2.1 & 1.2 & 1.3 & $<1.0$ \\
\hline Phenylacetaldehyde & 61.6 & 47.5 & 30.6 & 35.9 & $<1.0$ \\
\hline 2-phenylethanol & 11.9 & 3.2 & 2.7 & 24.6 & 13.2 \\
\hline Methyl benzoate & 1.5 & $<1.0$ & 2.0 & 1.7 & \\
\hline Benzyl acetate & & 60.5 & & & \\
\hline Phenethyl acetate & 11.3 & 29.0 & & 16.4 & $<1.0$ \\
\hline Phenethyl propionate & $<1.0$ & 1.0 & $<1.0$ & 1.1 & \\
\hline Phenethyl isobutyrate & $<1.0$ & $<1.0$ & $<1.0$ & $<1.0$ & \\
\hline Phenethyl isovaleratet & 5.2 & 12.7 & 1.2 & 9.6 & $<1.0$ \\
\hline Phenethyl senecioatet & $<1.0$ & $<1.0$ & $<1.0$ & 1.8 & \\
\hline Amyl salicylate & 1.0 & $<1.0$ & $<1.0$ & $<1.0$ & \\
\hline \multicolumn{6}{|l|}{ Fatty acid derivatives } \\
\hline Isopropyl isothiocyanate & & & & & 20.7 \\
\hline 2-methyl hexanoic acidt & 2.2 & 1.0 & 1.1 & $<1.0$ & \\
\hline Hexyl acetate & & $<1.0$ & & $<1.0$ & \\
\hline (Z)-3-hexen-1-ol & & & & & 28.8 \\
\hline (Z)-3-hexenyl acetate & & $<1.0$ & & $<1.0$ & 37.2 \\
\hline Total fresh mass $(\mathrm{g})$ & 4.57 & 5.58 & 6.54 & 3.39 & 0.50 \\
\hline Scent ng/g fresh mass $/ 8 \mathrm{~h}$ & 6.71 & 12.97 & 4.45 & 37.90 & 10.73 \\
\hline
\end{tabular}

*Per cent of total volatile emissions

tIndicates tentative identification due to mass spectrum library search. All other identifications verified by mass spectrum and retention time through coinjection of standards.

myrcene, (Z)-and (E)- $\beta$-ocimene, $\alpha$ - and $\beta$-pinene and, in Phlox, oxygenated monoterpenoids such as 1,8 cineole, linalool and verbenone (Table 4, Fig. 1). Ocimene was previously reported as the major floral volatile of the related european plant, Anemone (= Pulsatilla) vulgaris (Nilsson 1980), and monoterpene blends such as that identified from Pseudocymopteris montanus are characteristic of related umbellifers, such as Angelica spp. (Tollsten et al. 1994). Despite several attempts, we did not detect volatiles from the yellow flowers of Ranunculus inamoenus, which Puccinia pseudoflowers resemble most closely in size, shape and colour (Roy 1993a, 1994a). Floral headspace analyses of the related Ranunculus acris in Öland, Sweden revealed a scent profile dominated by (E)$\beta$-ocimene and other monoterpenes, 14 sesquiterpenes and about 1\% 2-phenylethanol (Bergström et al. 1995).

\section{Scent production and phylogenetic trends in the P. monoica complex}

Previous phylogenetic analyses based on DNA sequence variation in the ITS- 1 and ITS- 2 regions had revealed that both P. monoica and P. thlaspeos are polyphyletic 'species' (Roy et al. 1998). According to the phylogenetic hypothesis presented in Fig. 2, races of $P$. monoica using A. drummondii and A. holboellii as aecial hosts (Group II) bear a sister-group relationship to another clade (Group I) in which races of $P$. thlaspeos and P. monoica sharing $A$. demissa as a host are more closely related to each other than to conspecific races that use different Arabis hosts. P. consimilus appears to have evolved from within Group 1, and is most similar to rusts using A. demissa as an aecial host.

The evolution of scent chemistry is relatively conservative among these fungi, and is most parsimoniously explained in three steps. First, the emission of benzaldehyde, phenylacetaldehyde and 2-phenylethanol occurs in the basal taxon P. punctiformis, which lacks pseudoflowers but requires insect-mediated sexual reproduction (Connick \& French 1991). These three aromatic compounds, derived from phenylalanine through the shikimic acid pathway, are common to all taxa that we have examined within the more derived P. monoica complex, in which both pseudoflowers and insect-mediated sexual reproduction occur. Second, the phenylethyl esters are shared among all members of the P. monoica complex, but were not reported to be present in P. punctiformis by Connick \& French (1991). They must have arisen as components of pseudoflower fragrance after the historical split between the ancestors of $P$. punctiformis and the $P$. monoica complex (Fig. 2). Third, benzyl acetate is emitted exclusively by the derived taxon $P$. consimilis, is present 
Table 3 Volatiles emitted by Puccinia rust fungi associated with Arabis host plants: 1996

\begin{tabular}{|c|c|c|c|c|c|c|c|c|}
\hline $\begin{array}{l}\text { Chemical class } \\
\text { Compounds }\end{array}$ & $\begin{array}{l}\text { P. monoica on } \\
\text { A. holboellii }\end{array}$ & $\begin{array}{l}\text { P. monoica on } \\
\text { A. drummondii }\end{array}$ & \multicolumn{2}{|c|}{$\begin{array}{l}\text { P. consimilis on } \\
\text { A. crandallii }\end{array}$} & \multicolumn{2}{|c|}{$\begin{array}{l}\text { P. consimilis on } \\
\text { A. lignifera }\end{array}$} & \multirow[t]{2}{*}{$\begin{array}{l}\text { P. thlaspeos on } \\
\text { A. demissa }\end{array}$} & \multirow[t]{2}{*}{$\begin{array}{l}\text { P. thlaspeos on } \\
\text { A. gunnisoniana }\end{array}$} \\
\hline Aromatics & & & & & & & & \\
\hline Benzaldehyde & $7.6 \% *$ & & 6.4 & 6.8 & 5.6 & 1.1 & & \\
\hline Benzyl alcohol & & 3.6 & & & & & & \\
\hline Phenylacetaldehyde & 20.6 & $<1.0$ & 7.2 & 1.9 & 7.5 & 2.1 & $<1.0$ & $<1.0$ \\
\hline 2-phenylethanol & 20.2 & 1.4 & 16.2 & 12.4 & 20.0 & 15.2 & 50.9 & 29.4 \\
\hline Benzyl acetate & & & & $<1.0$ & & & & \\
\hline Phenethyl acetate & $<1.0$ & & $<1.0$ & 7.9 & $<1.0$ & 3.4 & & $<1.0$ \\
\hline Phenethyl propionate & $<1.0$ & & & $<1.0$ & & & & \\
\hline Phenethyl isobutyrate & $<1.0$ & & 3.1 & 1.2 & 5.6 & $<1.0$ & & $<1.0$ \\
\hline Phenethyl isovalerate & 8.6 & & 25.4 & 8.7 & 11.2 & 3.3 & $<1.0$ & $<1.0$ \\
\hline Phenethyl senecioatet & $<1.0$ & & 5.0 & $<1.0$ & 5.6 & $<1.0$ & & $<1.0$ \\
\hline \multicolumn{9}{|l|}{ Fatty acid derivatives } \\
\hline 2-methyl butanoate & & 5.4 & & 25.9 & & & & \\
\hline$n$-hexanal & & & & 5.7 & & & & 20.3 \\
\hline Hexyl acetate & & & & & & 2.2 & & \\
\hline 2-ethyl hexenol & & & & & & 1.1 & & \\
\hline (Z)-3-hexenal & 8.3 & 61.9 & 9.6 & 3.8 & 24.0 & 12.9 & 48.9 & 43.1 \\
\hline (Z)-3-hexenyl acetate & 23.8 & 20.0 & 20.9 & 15.8 & 14.9 & 34.5 & & $<1.0$ \\
\hline (Z)-3-hexenyl butanoate & 3.4 & 3.3 & 6.2 & & 5.6 & 5.0 & & \\
\hline $\begin{array}{l}\text { (Z)-3-hexenyl-3-methyl } \\
\text { butanoate }\end{array}$ & 7.7 & 4.5 & & 8.7 & & 15.2 & & 6.9 \\
\hline Fresh mass (g) & 3.66 & 1.10 & 2.30 & 2.18 & 1.26 & 1.72 & 1.42 & 0.60 \\
\hline $\mathrm{ng} / \mathrm{g}$ fresh mass $/ 8 \mathrm{~h}$ & 2.09 & 4.54 & 2.29 & 5.06 & 4.25 & 6.69 & 0.58 & 2.31 \\
\hline
\end{tabular}

*Per cent of total volatile emissions.

tIndicates tentative identification due to mass spectrum library search. All other identifications verified by mass spectrum and retention time through coinjection of standards.

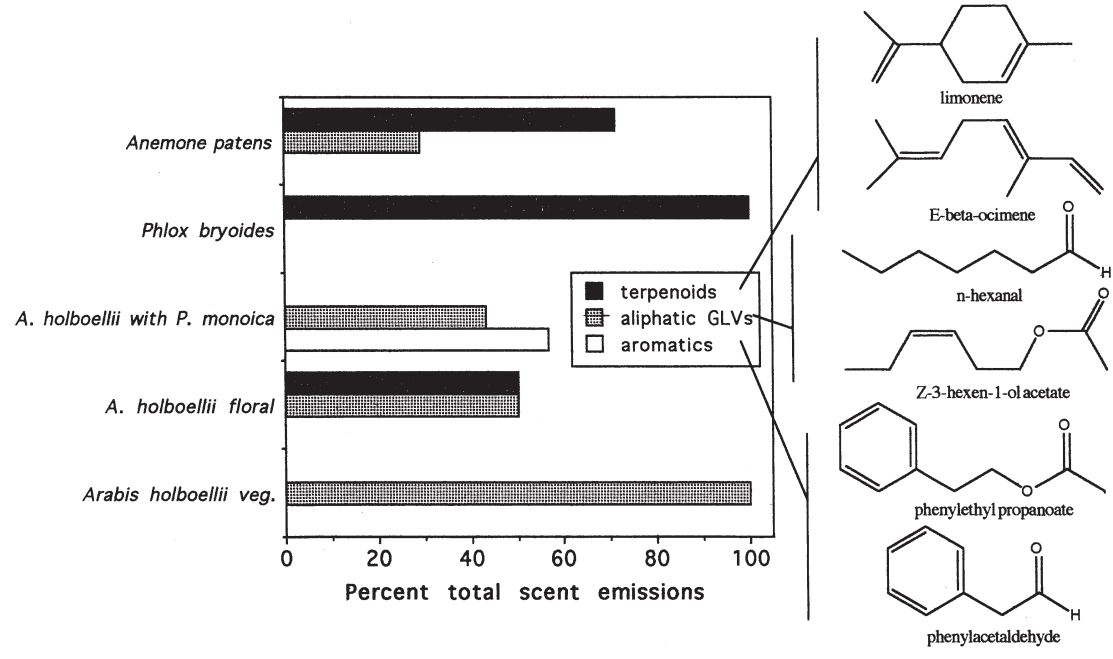

Fig. 1 Summary of qualitative differences in volatile composition, as measured using headspace trapping and GC-MS analysis, between uninfected Arabis holboellii tissues (mostly fatty-acid-derived products), tissues infected with Puccinia monoica (dominated by aromatic compounds), and coblooming plants (rich in terpendoid volatiles). Chemical structures of representative compounds from each biochemical class are provided. (Complete data are given in Tables 1-4.) only when $A$. crandallii is used as a host, and varies widely in relative emission rates (Tables 2 and 3, Fig. 2). This observed variation may represent a population-level polymorphism or may simply be a consequence of the unusually high variation in spore stage expression that characterizes the demicyclic P. consimilis (Roy et al. 1998).

\section{Discussion}

\section{Pseudoflower fragrance, insect attraction and floral} mimicry

Diverse groups of fungi interact with 'pollinators' and other insects, both to effect spore dispersal (Smith 1956; 
Table 4 Volatile compounds detected in coblooming plants

\begin{tabular}{|c|c|c|c|c|c|c|c|c|c|c|}
\hline \multirow{3}{*}{$\begin{array}{l}\text { Class } \\
\text { Compound }\end{array}$} & \multirow{3}{*}{$\begin{array}{l}\begin{array}{l}\text { Pseudocymopterus } \\
\text { montanus }\end{array} \\
1993 \\
\text { floral }\end{array}$} & \multicolumn{3}{|c|}{ Anemone patens } & \multicolumn{2}{|c|}{ Phlox bryoides } & \multicolumn{2}{|c|}{$\begin{array}{l}\text { Ranunculus } \\
\text { inamoenus }\end{array}$} & \multirow{2}{*}{\multicolumn{2}{|c|}{$\begin{array}{l}\text { Thlaspi } \\
\text { montanus } \\
1994\end{array}$}} \\
\hline & & \multirow{2}{*}{$\begin{array}{l}1994 \\
\text { floral }\end{array}$} & \multicolumn{2}{|l|}{1996} & \multicolumn{2}{|l|}{1994} & \multirow{2}{*}{$\begin{array}{l}1996 \\
\text { floral }\end{array}$} & \multirow{2}{*}{$\begin{array}{l}1996 \\
\text { floral }\end{array}$} & & \\
\hline & & & floral & veg. & floral & veg. & & & floral & veg. \\
\hline \multicolumn{11}{|l|}{ Terpenoids } \\
\hline $\begin{array}{l}\text { unknown }\left(\mathrm{C}_{9} \mathrm{H}_{16}\right) \\
\quad(\mathrm{mw} 135, \text { b. pk. 69) }\end{array}$ & & & & & 8.2 & 12.2 & \multirow{2}{*}{\multicolumn{2}{|c|}{$\begin{array}{l}\text { Scent not } \\
\text { detected }\end{array}$}} & & \\
\hline$\alpha$ pinene & & & & & 22.4 & 7.2 & & & 3.5 & \\
\hline$\beta$ pinene & $5.0 \% *$ & & & & & 4.3 & & & & \\
\hline Sabinene & 2.7 & & & & & 10.0 & & & & \\
\hline Myrcene & 36.9 & & & & 5.5 & & & & & \\
\hline$\delta$-carene & 3.0 & & & & & & & & & \\
\hline Limonene & & 2.8 & 3.8 & & 5.8 & & & & 15.0 & 18.7 \\
\hline (Z)- $\beta$-ocimene & 42.7 & 3.0 & $<1.0$ & & & & & & & \\
\hline (E)- $\beta$-ocimene & 6.5 & 94.2 & 66.5 & & & & & & & \\
\hline$\alpha$ terpinolene & & & & & 3.2 & & & & & \\
\hline Verbenone & & & & & 6.6 & & & & & \\
\hline Camphor & & & & & 8.4 & & & & & \\
\hline 1,8 cineole & & & & & 22.7 & 25.8 & & & & \\
\hline Linalool & & & & & 2.6 & & & & 7.5 & 10.1 \\
\hline Linalool oxide (furanoid) & & & & & 3.3 & & & & & \\
\hline Linalool oxcid (pyranoid) & & & & & & & & & 43.9 & 42.4 \\
\hline Nerol & & & & & & & & & 16.4 & \\
\hline Aromatics & & & & & & & Scent & & & \\
\hline Cymene & 3.2 & & & & & & detec & & & \\
\hline Benzaldehyde & & & & & & & & & 5.3 & 7.0 \\
\hline Benzyl alcohol & & & & 21.1 & & & & & & \\
\hline 1-propenyl benzenet & & & & 8.2 & & & & & & \\
\hline Propadienyl benzenet & & & & 17.6 & & & & & & \\
\hline \multicolumn{11}{|l|}{ Fatty acid derivatives } \\
\hline (Z)-3-hexen-1-ol & & & & & & 10.4 & & & & 6.0 \\
\hline (Z)-3-hexenyl acetate & & & & & & 13.0 & & & & $<1.0$ \\
\hline $\begin{array}{l}\text { (Z)-3-hexenyl } \\
\text { 3-methyl butyrate }\end{array}$ & & & & 36.3 & & & & & & \\
\hline 4-methyl nonanolt & & & 5.1 & & & & & & & \\
\hline Dodecanet & & & 24.1 & & & & & & & \\
\hline$\gamma$ valerolactonet & & & & 16.8 & & & & & & \\
\hline Valeric acid & & & & & & & & & 8.2 & \\
\hline Fresh mass (g) & 4.50 & 25.44 & 10.19 & 7.62 & 10.49 & 9.12 & 0.60 & 0.33 & 6.87 & 5.37 \\
\hline $\begin{array}{l}\text { Emissions, } \\
\mathrm{ng} / \mathrm{g} \text { fresh mass } / 8 \mathrm{~h}\end{array}$ & 7.52 & 0.40 & 1.48 & 0.33 & 1.47 & 0.91 & Not c & tected & 1.48 & 1.60 \\
\hline
\end{tabular}

*Percent of total volatile emissions.

tIndicates tentative identification due to mass spectrum library search. All other identifications verified by mass spectrum and retention time through co-injection of standards.

Alexander \& Antonovics 1988; Webber \& Gibbs 1989; Alexander 1990; Jennersten \& Kwak 1991; Lin \& Phelan 1992; Young 1993; Roy 1994b; Shykoff \& Bucheli 1995) and to mediate the exchange of mating-type gametes (Craigie 1931, Bultman \& White 1988; Connick \& French 1991; Roy 1993a). We have shown that Puccinia pseudoflowers use fragrance to attract bees and flies that pro- vide an essential 'pollination' service during the sexual cycle of these fungi (Roy \& Raguso 1997). Our surveys of scent production by Puccinia pseudoflowers, their Arabis hosts and coblooming true flowers demonstrate that pseudoflower fragrance is chemically distinct and consists entirely of aromatic alcohols, aldehydes and esters (Fig. 1, Tables 2 and 3). 


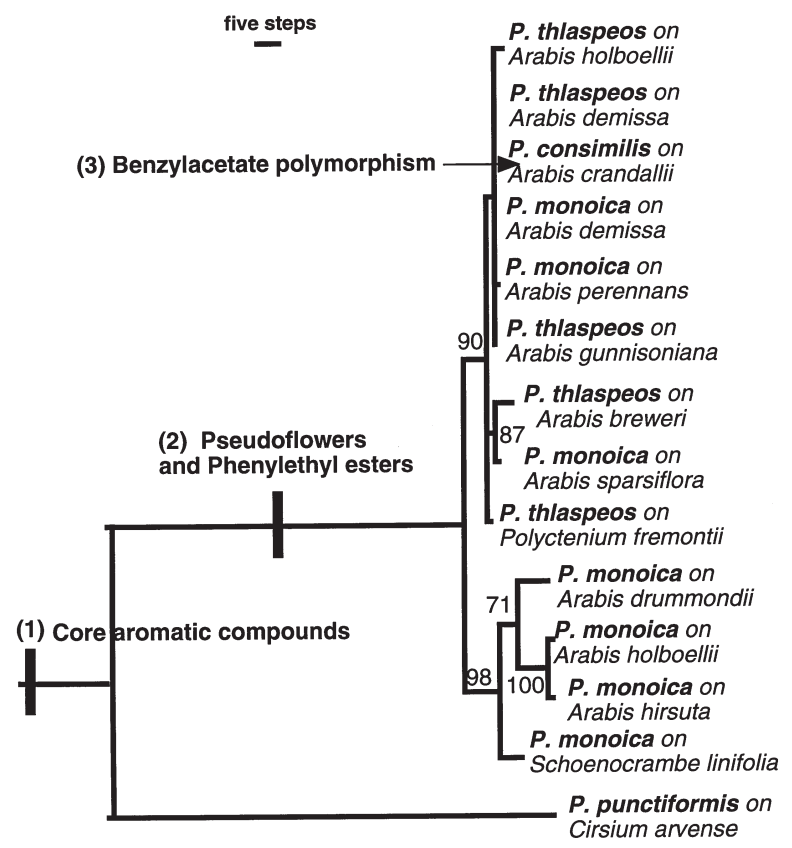

Fig. 2 Phylogram based on rDNA sequences from the ITS I, 5.8S and ITS II regions of the rust fungi studied for fragrance chemistry. The tree shown is the strict consensus of three trees found in a heuristic search with midpoint rooting. All characters were evenly weighted because the ti:tv ratio was essentially 1:1. Length, 234 steps; CI, 0.98; HI, 0.02; RI, 0.92. Bootstrap values for the branches are based on 1000 replicates. The hypothesized evolution of fragrance chemistry has been attached to the phylogram in the appropriate places (bold numbers in parentheses). For the crucifer rusts (all but Puccinia punctiformis) the molecular methods and phylogenetic analyses can be found in Roy et al. (1998). The sequence for P. punctiformis was obtained in the same manner as the crucifer rust sequences and is deposited in GenBank under Accession no. AF043476. P. punctiformis remains basal to the crucifer rusts when additional sequences from GenBank are included in the analysis (see Kropp et al. 1997).

Pseudoflower scent does not represent a simple amplification of host floral or vegetative emissions, nor does it appear to mimic the floral scent of four coflowering plants. The benzenoid compounds that characterize pseudoflower fragrance are emitted by numerous true flowers with diverse morphologies, pollinator spectra and phylogenetic affinities, including orchids pollinated by euglossine bees (Hills et al. 1972; Whitten \& Williams 1992), tubular, night-blooming flowers pollinated by hawkmoths (Knudsen \& Tollsten 1993), and especially small, nectar-rich flowers visited by noctuid moths (Cantelo \& Jacobson 1979; Haynes et al. 1991; Landolt et al. 1991; Heath et al. 1992a). Phenylacetaldehyde and 2phenyl ethanol are attractive to many species of noctuid moths and appear to be mating pheromone constituents of male hair pencil glands for at least some of these species (Creighton et al. 1973; Jacobson et al. 1976; Birch et al. 1989; but see Landolt \& Heath 1990; Heath et al. 1992b). Noctuid moths did not visit Puccinia pseudoflowers at our study sites in the Rocky Mountains, presumably because cool evening temperatures above $2700 \mathrm{~m}$ limit the moths' foraging activities after dark (Cruden et al. 1976), but they may be important visitors to pseudoflowers in warmer settings where Puccinia pseudoflowers are found, such as Moab, Utah, USA and Tucson, Arizona, USA. Perhaps fungal pseudoflowers are functionally most similar to the relatively unspecialized flowers of Edelweiss (Leontopodium alpinum; Asteraceae), which attract alpine flies, bees and other insects as pollinators and have hexose-dominated nectar, accessible, actinomorphic flowers and a fragrance that contains 2-phenylethanol, benzaldehyde and benzyl benzoate as well as terpenoids, GLVs and other 'goaty'-smelling aliphatic acids (Erhardt 1993).

The interactions between Puccinia fungal pseudoflowers and coblooming plants are complex, depending on relative population densities, floral species and class of insect visitor (Roy 1994a, 1996). Both pseudoflowers and true flowers benefit from each other's presence in attracting greater numbers of insects, but mixed visitation bouts by insects may have a negative impact via the improper placement of spermatia and pollen (Roy 1994a, 1996; see Inouye et al. 1994). While nectar rewards and visual cues such as colour, size, shape and habit suggest that fungal pseudoflowers are generalized mimics of true flowers (Roy 1993a, 1994a), we have demonstrated that their fragrances are chemically distinct from at least four species of coblooming flowers and from the flowers of their Arabis hosts. Even if subsequent analyses prove that low levels of 2-phenylethanol or similar aromatic compounds are present in Ranunculus inamoenus, its probable combination with terpenoid compounds (see Bergström et al. 1995) render it olfactorily distinct from the pseudoflower fragrance blends. Clearly, the emission of benzaldehyde, 2-phenylethanol and phenylacetaldehyde by spermatia is an ancestral condition among insect-fertilized Puccinia rust fungi, and is independent of the floral community that we describe from the Rocky Mountains of Colorado. However, it is possible that these chemically distinct fragrances may be important in the mimicry system if insects initially choose to forage in a patch due to density-dependent visual cues, but then home in on specific taxa based on their distinct fragrances. Distinctive fragrances may thus reduce gamete loss via olfactory reinforcement of visitor constancy among foraging flower visitors.

\section{Fungal odours and their biochemical origins}

The volatiles emitted by Puccinia pseudoflowers are intriguing in that all are benzyl alcohols, aldehydes or esters, structurally related metabolites of a single biosynthetic pathway that is abundantly expressed in other 
basidiomycetes, including Polyporus tuberaster (Kawabe and Morita 1994) and P. hispidus (French et al. 1976), and the genera Agaricus, Armillaria, Hygrophoris and Lepiota (Arora 1986). Although pseudoflower fragrance is chemically distinct from vegetative and floral volatiles produced by host Arabis plants (Fig. 1), it remains possible that fungal spermatial tissue produces fragrance by modifying host-plant metabolites, rather than synthesizing their own fragrance compounds de novo. This hypothesis follows from Connick \& French's (1991) study, which demonstrated that the three benzenoid scent compounds emitted by P. punctiformis also were present in the insectpollinated flowers of the host thistle plant (Cirsium arvense). A fourth compound, the nitrogen-bearing aromatic indole, was the major volatile detected in P. punctiformis (Connick and French 1991), and is a ubiquitous metabolite of tryptophan and auxin in all plants (reviewed by Romero et al. 1995). Indole was either not detected or present at low, inconsistent levels in our survey of the P. monoica complex (Tables 2 and 3). Rather than an evolutionary loss, this pattern may reflect a methodological artefact, in that Connick \& French (1991) used thermal desorption, a more sensitive method, to elute trapped scent compounds from $P$. punctiformis, while we used hexane solvent desorption, and indole is poorly soluble in hexane (Raguso \& Pellmyr 1998).

In contrast to the Cirsium-P. punctiformis relationship, most of the Arabis hosts of the P. monoica rust complex produce small, nearly scentless flowers that are either apomictic ( $A$. holboellii, A. gunnisoniana and A. lignifera) or predominantly self-pollinating ( $A$. drummondii and $A$. crandallii) (Roy 1995). From a synomonal standpoint, floral scent would be superfluous in these flowers. However, benzaldehyde, phenylacetaldehyde and 2-phenylethanol have been detected as floral fragrance constituents in larger, insect-pollinated cruciferous flowers (Tollsten \& Bergström 1988; Evans \& Allen-Williams 1992; Jakobsen et al. 1994; Nielsen et al. 1995), and they are common products of the ubiquitous shikimate biosynthetic pathway, leading from phenylalanine to benzoic acid and phenylpropanoid products (reviewed by Dixon \& Paiva 1995; Schmid \& Amrhein 1995). The presence of benzaldehyde and benzyl alcohol in bolting Arabis foliage (Table 1) suggests that their precursors, and those of the phenolic acetates and esters, are doubtless available within the tissues of Arabis host plants. On the other hand, fungi are noteworthy for their biochemical versatility, producing a wide assortment of volatile organic compounds, including phenolics (Arora 1986; Kawabe \& Morita 1994), derived mono- and sesquiterpenoids (Hanssen 1985; Bock et al. 1986), fatty acid derivatives (Tressl et al. 1982; Grosh \& Wurzenberger 1984; Armstrong 1986; Lin \& Phelan 1992; Noël-Suberville et al. 1996) nitrogen- (indolic) and sulphur-bearing organic compounds (Bau 1981; Chen et al. 1986; Talou et al. 1989; Pelusio et al. 1995). Thus, Puccinia fungal pseudoflowers are, in theory, capable of synthesizing their own fragrance compounds. The qualitative and quantitative differences in scent emissions between 'conspecific' fungal taxa on different Arabis hosts (P. thlaspeos on A. demissa vs. A. gunnisoniana [Table 2], $P$. consimilus on $A$. crandallii vs. A. lignifera [Table 3]) suggest that differences in host physiology may translate into differences in host metabolite pools available for scent production. Alternatively, the presence of cryptic host race 'species' within the P. monoica complex (Roy et al. 1998), combined with the potential for sampling error in our surveys, undermines the strength of such comparisons. Radiolabel tracer experiments or tissue-specific enzymatic assays are recommended for future efforts to distinguish between these conflicting hypotheses.

\section{Acknowledgements}

We are grateful to Wendy Brown for help with collecting plant and fungal samples, to Larry Evanicky and Kevin Moore for GCMS expertise, and to John Hildebrand for the use of his GC-MS facility. R.A.R. was supported by NIH training grant no. T32AI07475 and NSF grant no. MCB9218989 to E. Pichersky (University of Michigan), and by an NIH Postdoctoral Training Grant to the Center for Insect Science, University of Arizona. B.A.R. was supported by an NSF Postdoctoral Fellowship (BSR 9103799) and by a grant from the Swiss National Fund (3100-046865.96).

\section{References}

Alexander H (1990) Epidemiology of anther-smut infection of Silene alba caused by Ustilago violacea: patterns of spore deposition and disease incidence. Journal of Ecology, 78, 166-179.

Alexander H, Antonovics J (1988) Disease spread and population dynamics of anther-smut infection of Silene alba caused by the fungus Ustilago violacea. Journal of Ecology, 76, 91-104.

Armstrong D (1986) Selective production of ethyl acetate by Candida utilis. In: Biogeneration of Aromas (eds Parliment T, Croteau R), pp. 254-265. American Chemical Society, Washington DC.

Arora D (1986) Mushrooms Demystified, 2nd edn. Berkeley, CA: Ten Speed Press.

Audouin P, Vidal J-P, Richard H (1989) Volatile compounds from aroma of some edible mushrooms: morel (Morchella conica), wood blewit (Lepista nuda), clouded agaric (Clitocybe nebularis) and false chanterelle (Hygrophoropsis aurantiaca). Scientific Aliments, 9, 185-193.

Bau Y-S (1981) Indole compounds in Saccharomyces cerevisiae and Aspergillus niger. Botanical Bulletin Academia Sinica, 22, 123-130.

Bergström G, Dobson H, Groth I (1995) Spatial fragrance patterns within the flowers of Ranunculus acris (Ranunculaceae). Plant Systematics and Evolution, 195, 221-242.

Birch M, Lucas D, White P (1989) The courtship behavior of the cabbage moth, Mamestra brassicae (Lepidoptera: Noctuidae) and the role of male hair pencils. Journal of Insect Behavior, 2, 227-239. 
Bock G, Benda I, Schreier P (1986) Metabolism of linalool by Botrytis cinerea. In: Biogeneration of Aromas (eds Parliment T, Croteau R), pp. 243-253, American Chemical Society, Washington DC.

Bultman T, White J (1988) 'Pollination' of a fungus by a fly. Oecologia, 73, 317-319.

Buttery R, Ling L (1993) Volatile components of tomato fruit and plant parts. In: Bioactive volatile compounds from plants (eds Teranishi R, Buttery R, Sugisawa H), pp. 23-34, American Chemical Society, Washington, DC.

Cantelo W, Jacobson M (1979) Phenylacetaldehyde attracts moths to bladder flower and to blacklight traps. Environmental Entomology, 8, 444-447.

Chen C, Liu S, Wu C, Ho C (1986) Enzymic formation of volatile compounds in shiitake mushroom (Lentinus edodes Sing.). In: Biogeneration of Aromas (eds Parliment T, Croteau R), pp. 176-183, Washington DC: American Chemical Society.

Connick W Jr, French R (1991) Volatiles emitted during the sexual stage of the Canada thistle rust fungus and by thistle flowers. Journal of Agricultural and Food Chemistry, 39, 185-188.

Craigie J (1931) An experimental investigation of sex in the rust fungi. Phytopathology, 21, 1001-1040.

Creighton C, McFadden T, Cuthbert E (1973) Supplementary data on phenylacetaldehyde: an attractant for Lepidoptera. Journal of Economic Entomology, 66, 114-115.

Croteau R, Karp F (1991) Origin of natural odorants. In: Perfumes - Art, Science and Technology (eds Müller P, Lamparsky D), pp. 101-126. Elsevier Applied Science, NY.

Cruden R, Kinsman S, Stockhouse R, Linhart Y (1976) Pollination, fecundity and the distribution of moth-flowered plants. Biotropica, 8, 204-210.

Dickens J, Smith J, Light D (1993) Green leaf volatiles enhance sex attractant pheromone of the tabacco budworm, Heliothis virescens (Lepid. Noctuidae). Chemoecology, 4, 175-177.

Dixon R, Paiva N (1995) Stress-induced phenylpropanoid metabolism. The Plant Cell, 7, 1085-1097.

Erhardt A (1993) Pollination of the edelweiss, Leontopodium alpinum. Botanical Journal of the Linnaen Society, 111, 229-240.

Evans K, Allen-Williams L (1992) Electroantennogram responses of the cabbage seed weevil, Ceutorhynchus assimilis, to oilseed rape, Brassica napus ssp. oleifera volatiles. Journal of Chemical Ecology, 18, 1641-1658.

Fenwick G, Heaney R, Mullin W (1983) Glucosinolates and their breakdown products in food and food plants. CRC Critical Review of Food Science and Nutrition, 18, 183-201.

French C, Vance C, Towers R (1976) Conversion of p-coumaric acid to p-hydroxybenzoic acid by cell free extracts of potato tubers and Polyporus hispidus. Phytochemistry, 15, 564-566.

Grosh W, Wurzenberger M (1984) Enzymic formation of 1-octen3-ol in mushroom. Developments in Food Science, 10, 253-259.

Hanssen H-P (1985) Sesquiterpene alcohols from Lentinus lepideus. Phytochemistry, 24, 1293-1294.

Haynes K, Zhao Z, Latif A (1991) Identification of floral compounds from Abelia grandiflora that stimulate upwind flight in cabbage looper moths. Journal of Chemical Ecology, 17, 637-646.

Heath R, Landolt P, Dueben B, Lenczewski B (1992a) Identification of floral compounds of night-blooming jessamine attractive to cabbage looper moths. Environmental Entomology, 21, 854-859.

Heath R, Landolt P, Dueben B, Murphy R, Schneider R (1992b) Identification of male cabbage looper sex pheromone attractive to females. Journal of Chemical Ecology, 18, 441-453.
Hills H, Williams N, Dodson C (1972) Floral fragrances and isolating mechanisms in the genus Catasetum (Orchidaceae). Biotropica, 4, 61-76.

Inouye D, Gill D, Dudash M, Fenster C (1994) A model and lexicon for pollen fate. American Journal of Botany, 81, 1517-1530.

Jacobson M, Adler V, Kishaba A, Priesner E (1976) 2Phenylethanol, a presumed sexual stimulant produced by the male cabbage looper moth, Trichoplusia ni. Experientia, 32, 964-966.

Jakobsen H, Friis P, Nielsen J, Olsen C (1994) Emission of volatiles from flowers and leaves of Brassica napus in situ. Phytochemistry, 37, 695-699.

Jennersten O, Kwak M (1991) Competition for bumblebee visitation between Melampyrum pratense and Viscaria vulgaris with healthy and Ustilago-infected flowers. Oecologia, 86, 88-98.

Kawabe T, Morita H (1994) Production of benzaldehyde and benzyl alcohol by the mushroom Polyporus tuberaster K2606. Journal of Agricultural and Food Chemistry, 42, 2556-2560.

Knudsen J, Tollsten L (1993) Trends in floral scent chemistry in pollination syndromes: floral scent composition in moth-pollinated taxa. Botanical Journal of the Linnaean Society, 113, 263-284.

Kropp BR, Hansen DR, Wolf PG, Flint M, Thomson S (1997) A study on the phylogeny of the Dyer's Woad rust fungus and other species of Puccinia from crucifers. Phytopathology, 87, 565-571.

Landolt P, Heath R (1990) Sexual role reversal in mate-finding strategies of the cabbage looper moth. Science, 249, 1026-1028.

Landolt P, Lenczewski B, Heath R (1991) Lure and toxicant system for the cabbage looper (Lepidoptera: Noctuidae). Journal of Economic Entomology, 84, 1344-1347.

Lin H, Phelan PL (1992) Comparison of volatiles from beetletransmitted Ceratocystis fagacearum and four non-insectdependent fungi. Journal of Chemical Ecology, 18, 1623-1632.

Mookherjee B, Wilson R, Trenkle R, Zampino M, Sands K (1989) New dimensions in flavor research. In: Flavor Chemistry; Trends and Developments (eds Teranishi R, Buttery R, Shahidi F), pp. 177-187. American Chemical Society, Washington, DC.

Nielsen J, Jakobsen H, Friis P, Hansen K, Møller J, Olsen C (1995) Asynchronous rhythms in the emission of volatiles from Hesperis matronalis flowers. Phytochemistry, 38, 847-851.

Nilsson LA (1980) The pollination ecology of Dactylorhiza sambucina (Orchidaceae). Botaniska Notiser, 133, 367-385.

Noël-Suberville C, Cruz C, Guinberteau J, Montury M (1996) Correlation between fatty acid content and aromatic compound release in fresh blewit (Lepista nuda). Journal of Agricultural and Food Chemistry, 44, 1180-1183.

Pelusio F, Nilsson T, Montanarella L, Tilio R, Larsen B, Facchetti S, Madsen J (1995) Headspace solid-phase microextraction analysis of volatile organic sulfur compounds in black and white truffle aroma. Journal of Agricultural and Food Chemistry, 43, 2138-2143.

Raguso R, Pellmyr O (1998) The analysis of floral scent through dynamic headspace collection; a comparison of methods. Oikos, 81, 238-254.

Romero R, Roberts M, Phillipson J (1995) Anthranilate synthase in microorganisms and plants. Phytochemistry, 39, 263-276.

Roy B (1993a) Floral mimicry by a plant pathogen. Nature, 362, $56-58$.

Roy B (1993b) Patterns of rust infection as a function of host genetic diversity and host density in natural populations of the apomictic crucifer, Arabis holboellii. Evolution, 47, 111-124. 
Roy B (1994a) The effects of pathogen-induced pseudoflowers and buttercups on each other's insect visitation. Ecology, 75, 352-358.

Roy B (1994b) The use and abuse of pollinators by fungi. Trends in Ecology and Evolution, 9, 335-339.

Roy B (1995) The breeding systems of six species of Arabis (Brassicaceae). American Journal of Botany, 82, 869-877.

Roy B (1996) A plant pathogen influences pollinator behavior and may influence reproduction of non-hosts. Ecology, 77, 2445-2457.

Roy B, Bierzychudek P (1993) The potential for rust infection to cause natural selection in apomictic Arabis holboellii (Brassicaceae). Oecologia, 95, 533-541.

Roy B, Raguso R (1997) Olfactory versus visual cues in a floral mimicry system. Oecologia, 109, 414-426.

Roy B, Vogler D, Bruns T, Szaro T (1998) Cryptic species in the Puccinia monoica complex. Mycologia, 90, 847-854.

Schmid J, Amrhein N (1995) Molecular organization of the shikimate pathway in higher plants. Phytochemistry, 39, 737-749.

Shykoff J, Bucheli E (1995) Pollinator visitation patterns, floral rewards and the probability of transmission of Microbotryum violaceum, a venereal disease of plants. Journal of Ecology, 83, 189-198.

Smith K (1956) Proceedings of the Royal Entomological Society of London, Serial A. General Entomology, 31, 49-55.

Talou T, Delmas M, Gaset A (1989) New trends in black truffle aroma analysis. In: Flavor Chemistry: Trends and Developments (eds Teranishi R, Buttery R, Shahidi F), pp. 202-212. American Chemical Society, Washington DC.

Tollsten L, Bergström G (1988) Headspace volatiles of whole plants and macerated plant parts of Brassica and Sinapis. Phytochemistry, 27, 2073-2077.
Tollsten L, Knudsen J, Bergström G (1994) Floral scent in generalistic Angelica (Apiaceae) - an adaptive character? Biochemical Systematics and Ecology, 22, 161-169.

Tressl R, Bahri D, Engel K-H (1982) Formation of eight carbon and ten carbon components in mushrooms (Agaricus campestris). Journal of Agricultural and Food Chemistry, 30, 89-93.

Visser J, Avé D (1978) General green leaf volatiles in the olfactory orientation of the Colorado beetle, Leptinofarsa decemlineata. Entomologia Experimentalis et Applicata, 24, 538-549.

Webber J, Gibbs J (1989) Insect dissemination of fungal pathogens of trees. In: Insect-Fungus Interactions. (eds Wilding N, Collins N, Hammond P, Webber J), pp. 161-189. Academic Press, London.

Whitten WM, Williams N (1992) Floral fragrance of Stanhopea (Orchidaceae). Lindleyana, 7, 130-153.

Young AM (1993) Sarapiqui Chronicle: a Naturalist in Costa Rica. Smithsonian Institution Press, Washington, DC.

Robert Raguso and Bitty Roy are interested in the roles of olfactory and visual signals in insect-plant and insect-fungal interactions, and the mechanisms by which such interactions evolve. A major goal of our research is to track the sequence of evolutionary modifications in a floral-mimicry system, to understand how pathogenic fungi have 'reinvented' the rewards and advertisements used by flowering plants to attract pollinators and effect outcrossing. This paper describes chemical analyses of fungal 'floral scent', which were used previously to guide behavioural bioassays and field experiments, within a phylogenetic framework provided by the analysis of independent molecular markers. 